\title{
Technical method
}

\section{A histochemical method for the determination of titanium in tissues surrounding implants}

\author{
D. F. WILliams and D. ADAMS School of Dental \\ Surgery, University of Liverpool
}

Titanium is now accepted as a biocompatible implant material and is extensively used in orthopaedics, oral surgery, and neurosurgery. It is generally found to be well tolerated by both soft and hard tissues. It is known, however, that the tissue adjacent to titanium implants does contain some titanium after a period of implantation. Laing et al (1967) and Meachim and Williams (1973) found, using different techniques on gross tissue samples, that the titanium concentration in tissues adjacent to titanium implants was significantly higher than in control specimens.

Histological examination of the tissue frequently revealed particulate matter which was morphologically indistinguishable from haemosiderin and gave a positive Perls stain for ferric iron. Some, however, gave a negative stain for ferric iron and appeared dark-brown or black in haematoxylin and eosin stained sections. This material is responsible for the discolouration often noted on naked-eye examination of the tissue samples.

It is not known what is the nature of these particles although it is natural to assume that they contain titanium. The metal itself does not corrode in the body because an ultrathin protective layer of oxide forms on the metal surface, preventing further interaction between the titanium and the environment. It is possible, however, for there to be a very slow diffusion of titanium ions through the oxide layer, and also a very slow dissolution of the outer surface of the layer (Williams, 1976). In those cases where the titanium is used for the replacement of hard tissue, some wearing of the surface, against either bone or another prosthetic component, may also take place.

The usual histological stains do not provide any evidence concerning the nature of the particles in the tissue surrounding titanium implants. Hitherto it has been possible to analyse the gross tissue sample only for total titanium content. It is the purpose of this paper to describe a modification of a histochemical method, originally described by De Vries and Meijer (1968), which is able to confirm whether these particles do contain titanium and which may be used in a routine pathology laboratory.

\section{Material and methods}

Titanium powder and titanium dioxide powder was surgically placed in the leg muscles of 10 adult black-and-white hooded rats anaesthetized with veterinary nembutal. At weekly intervals between 8 and 12 weeks, two animals were sacrificed, and blocks of muscle were removed from the area of implantation, fixed in formol saline, and blocked in paraffin wax. As a control for the method, salts of six other metals, which may commonly be found in implant materials, were inserted, and sections from these animals were subjected to the technique. The salts were those of aluminium, cobalt, copper, chromium, iron, and nickel and were identified as being present in the sections by standard inorganic spot tests (Vogel, 1962) which are outlined in the table. In vitro tests were also carried out to confirm that the above salts did not interfere with the identification of titanium. Once the technique had been standardized using animal tissue it was then used on human tissue from around a titanium implant which had been removed surgically. Human control material was provided by tissue known to contain graphite particles which by routine histology gave an appearance similar to the titanium sections.

\section{THE MICROINCINERATION FURNACE}

An electric furnace was constructed for the mineralization of the sections. Figure 1 shows a diagram of

\begin{tabular}{|c|c|}
\hline Salt & Confirmatory Test \\
\hline Aluminium & $\begin{array}{l}\text { One drop of saturated alcoholic alizarin put on sec- } \\
\text { tion and slide held in ammonia fumes; a red/violet } \\
\text { colouration results }\end{array}$ \\
\hline Cobalt & $\begin{array}{l}\text { Slide held in ammonia fumes and then one drop of } \\
1 \% \text { solution of rubeanic acid in alcohol added; a } \\
\text { yellow/brown precipitate results }\end{array}$ \\
\hline $\begin{array}{l}\text { Copper } \\
\text { Chromium }\end{array}$ & $\begin{array}{l}\text { As cobalt; a black precipitate results } \\
\text { A green precipitate with the addition of sodium } \\
\text { phosphate solution }\end{array}$ \\
\hline $\begin{array}{l}\text { Iron } \\
\text { Nickel }\end{array}$ & $\begin{array}{l}\text { Dark blue precipitate with potassium ferricyanide } \\
\text { As cobalt; a blue precipitate results }\end{array}$ \\
\hline
\end{tabular}




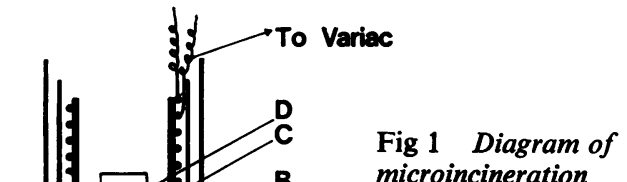
microincineration furnace. For explanation see text.

the apparatus and the essential parts. The tubes are made of Pyrex-glass.

A Tube measuring $37 \times 25 \mathrm{~mm}$ on which the slides carrying the sections are placed back to back

B Tube measuring $305 \times 25 \mathrm{~mm}$ and closed at one end. An indentation on the lower side of tube $B$ fits over the end of a steel rod $L$. The tube is also provided with four small glass bulbs to keep it concentric with respect to a tube $\mathrm{G}$. The thickened upper side of the tube is polished smooth. During the heating process this tube can be covered with

C A plate of Pyrex-glass

D A stainless steel weight

E Rubber stopper with two holes, the central one receiving the steel rod $L$, the other admitting air via tube $J$

G Tube measuring $570 \times 34 \mathrm{~mm}$, around which is wound the wire from a $1-\mathrm{kW}$ electric fire element secured at each end by a brass bracket. The connecting wires are fibreglassinsulated and come out between tubes $\mathbf{G}$ anc $H$. Tube $G$ is kept centrally within $H$ by asbestos strips at the top and by the stopper Ees at the bottom. The furnace is connected to the mains via a Variac; thus by placing thermocouple leads between tubes $H$ and $K \vec{w}$ setting may be obtained which maintains की temperature of $450^{\circ} \mathrm{C}$ within the furnace

H Tube measuring $630 \times 55 \mathrm{~mm}$ in which the rubber stopper is mounted

J Tube to admit compressed air

$\mathrm{K}$ Tube measuring $650 \times 70 \mathrm{~mm}$ resting on a metal mantel made of aluminium sheet and serving to attach the oven to the wall. Tubes $\mathbf{H}$ and $\mathbf{K}$ provide for heat insulation and as safety measure in case of breakage of tubes. B or $\mathbf{G}$

L Steel rod, $5 \mathrm{~mm}$ in cross-section, by which the height of tube $B$ can be controlled.

\section{SOLUTIONS}

$10 \%$ aqueous solution of sodium metasilicate filtereक through 42 filter paper

$10 \%$ aqueous solution of tannic acid filtered through

42 filter paper

PROCEDURE

1 Six sections are deparaffinized in xylene, rinsed in absolute ethanol, and air dried.

2 After a 10-second immersion in the sodium metasilicate solution the slides are centrifuged for several mintes at $2000 \mathrm{rev} / \mathrm{min}$ and are ther carefully cleaned.

3 Two drops of concentrated sulphuric acid are placed in tube $B$, and the slides are placed in it back to back in pairs and at right angles to eachㄹ.․

4 The height of tube B is adjusted by means of rod $L$ until the slides are within the heating coil but the bottom of the tube containing the sulphuricu acid is without. The furnace is switched on and left for at least $\mathbf{3 0}$ minutes.

5 After this time tube $B$ is raised until the sulphurice acid is just seen to boil.

6 After a further 30 minutes tube $B$ is lowered to its original level, the power is turned off, and compressed air is introduced.

7 As soon as the slides are cool enough they are removed with a pair of long tweezers and placed in the tannic acid solution. 


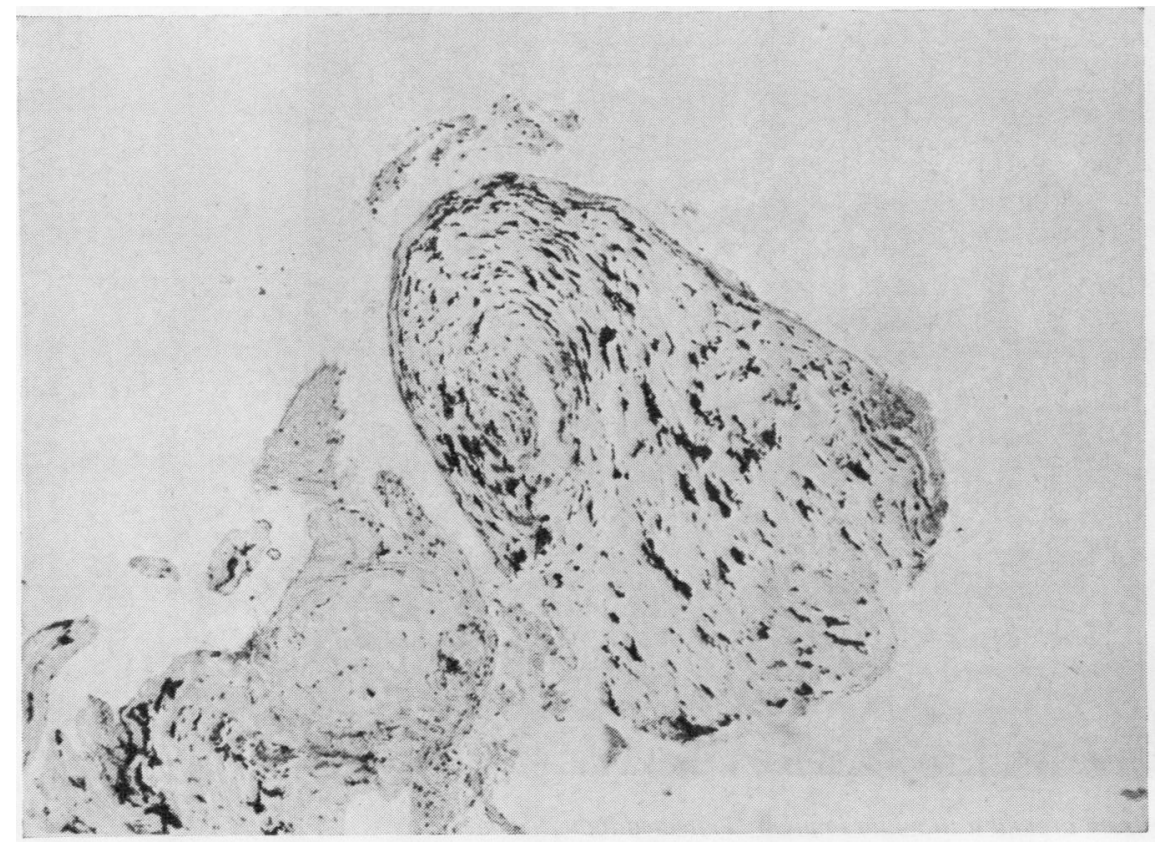

Fig 2 A section of tissue from around a titanium implant. Transmitted light. Haematoxylin and eosin $\times 36$.

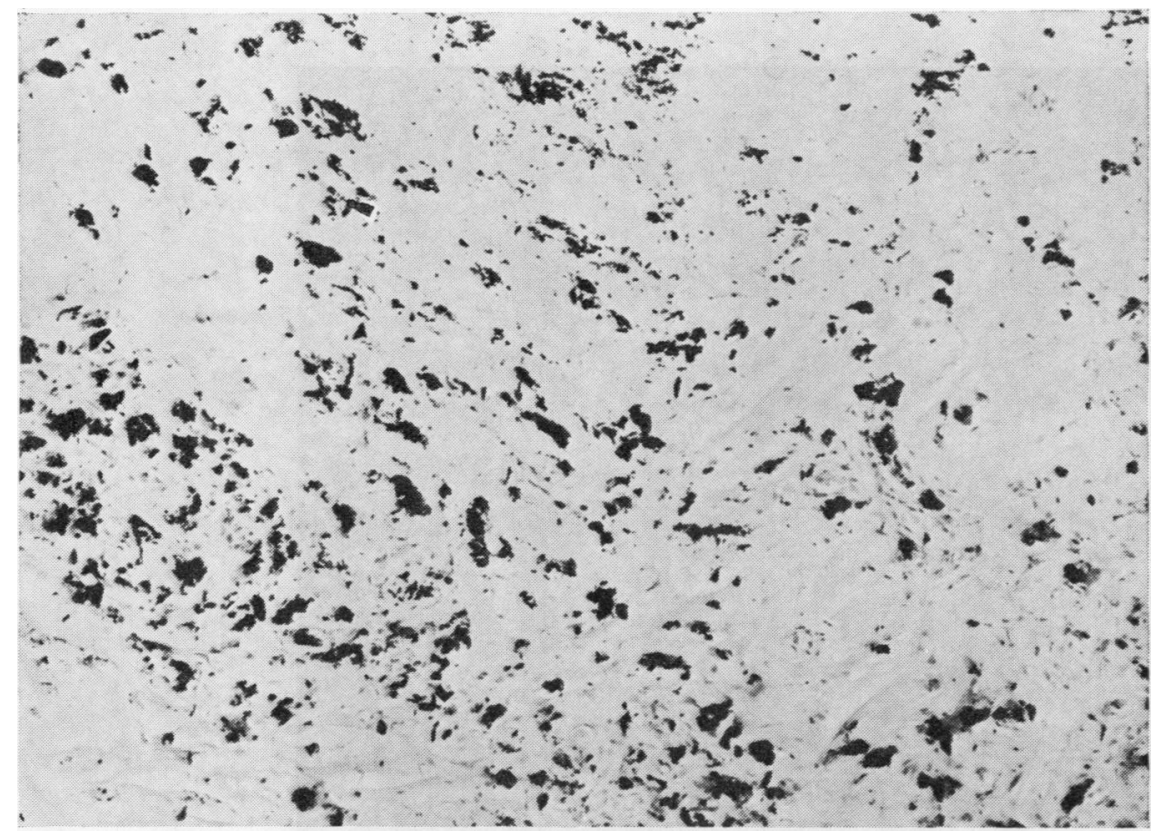

Fig 4 A section of tissue containing graphite. Transmitted light. $H$ and $E \times 36$. 


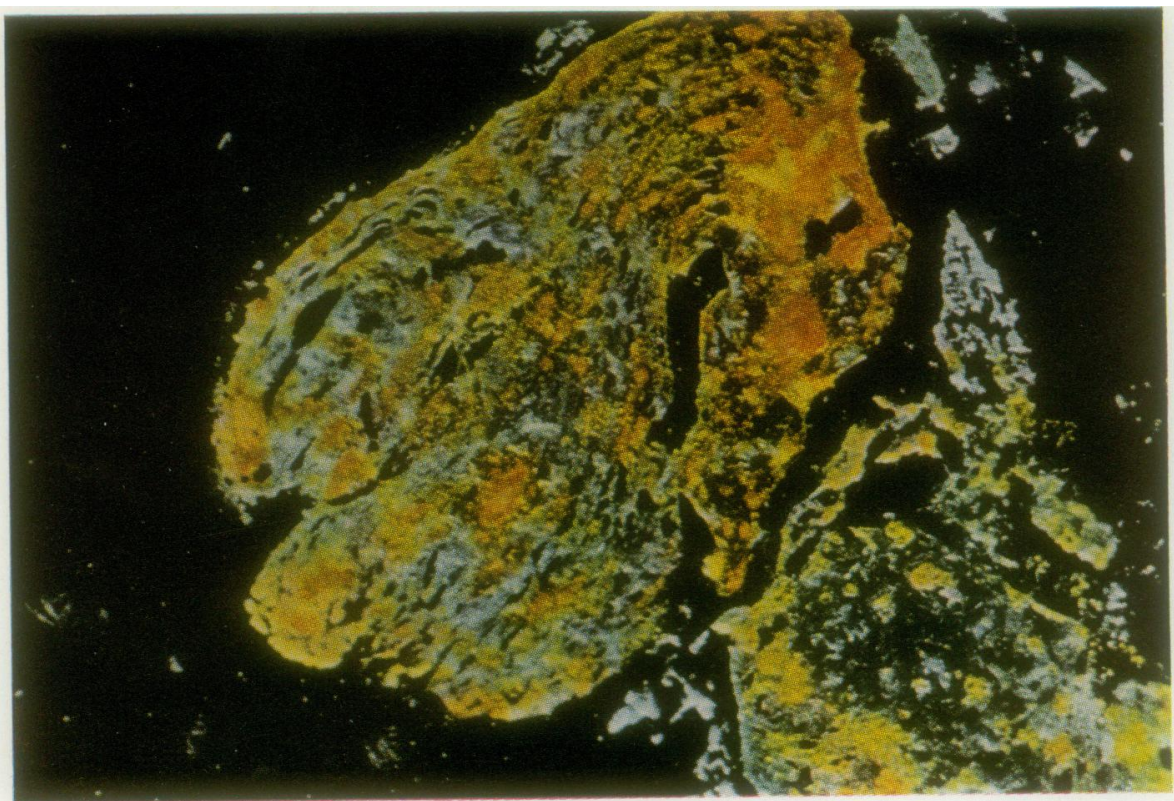

Fig 3 A section of tissue from around a titanium implant. Reflected light. Tannic acid $\times 80$.

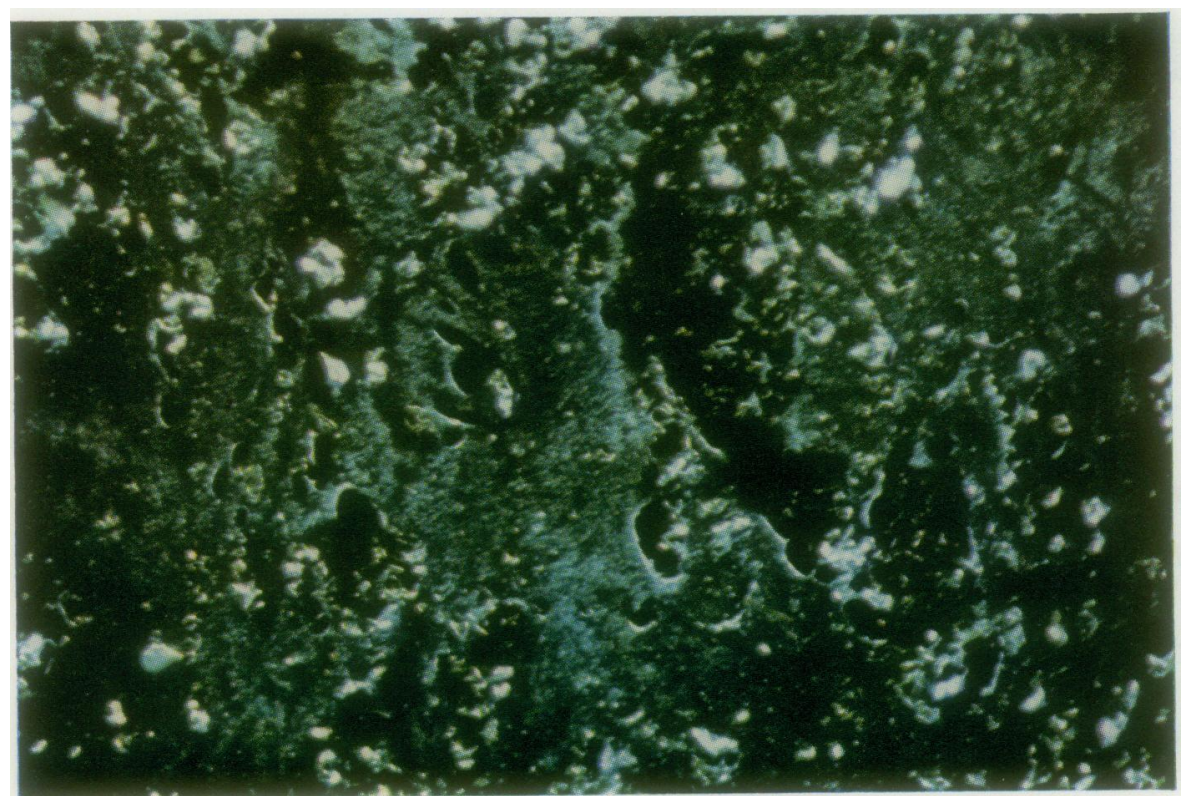

Fig 5 A section of tissue containing graphite. Reflected light. Tannic acid $\times 80$. 
8 After five seconds' staining they are removed and briefly passed through water, $60 \%$ acetone, and acetone and then air dried.

9 The slide may be viewed using bright field transmitted light when titanium-containing areas appear yellow. Better visualization is achieved using reflected light with dark field illumination.

\section{Results}

Immersion of the section in sodium metasilicate ensures good reproduction of the original tissue morphology as this forms insoluble silicium dioxide when heated. The initial heating period converts any metal present to its oxide which in turn is converted to the sulphate by the sulphuric acid. Titanyl sulphate then forms a yellow precipitate with the tannic acid solution.

The series of controls showed that:

1 This sequence of chemical changes takes place with titanium salts in vitro and no interference is experienced when aluminium, cobalt, copper, chromium, iron or nickel are present.

2 A yellow precipitate is not produced by any of these other salts using the same technique.

3 Titanium may be identified in animal tissue after impregnation of the tissue with titanium salts using this technique.

Figure 2 shows a section of human tissue obtained from the location of a titanium implant that has been stained with haematoxylin and eosin while fig 3 shows a further section stained using the technique described. Figures 4 and 5 show sections of human tissue containing graphite that have been stained by the same methods, illustrating the similarity of the two haematoxylin and eosin stained sections but the differences between titanium- and non-titaniumbearing sections when stained with tannic acid.

Our thanks are due to $\mathrm{Mr} \mathrm{G}$. Abbott for construction of the microincineration furnace, to Miss $\mathrm{E}$. Mort for technical assistance, to $\mathrm{Mr}$ J. S. Bailie and the Department of Medical Illustration for the illustrations, and to Dr G. Meachim for advice and provision of the graphite-containing material.

\section{References}

De Vries, G. and Meijer, A. E. F. H. (1968). Histochemical method for identification of titanium and iron oxides in pulmonary dust deposits. Histochemie, 15, 212-218.

Laing, P. G., Ferguson, A. B. Jr., and Hodge, E. S. (1967). Tissue reaction in rabbit muscle exposed to metallic implants. J. biomed. Mater. Res., 1, 135-149.

Meachim, G. and Williams, D. F. (1973). Changes in nonosseous tissue adjacent to titanium implants. J. biomed. Mater. Res., 7, 555-572.

Vogel, A. I. (1962). A Text-book of Macro and Semimicro Qualitative Inorganic Analysis. Longmans, London.

Williams, D. F. (1976). Corrosion of implant materials. Ann. Rev. Mater. Sci., 6 (In press).

\section{Letters to the Editor}

No mouse model for $H$. influenzae infection

In a recent series of experiments investigating the toxic components of $H$. influenzae type b, an animal model was required for the demonstration of possible in vivo effects.

There are several reports on the effects of injecting or inoculating rabbits and rats with $H$. influenzae (Schneerson and Robbins, 1971; Smith et al, 1973; Moxon et al, 1974). As in humans, rabbits show an age-dependent susceptibility (with a maximum susceptibility at three weeks), which is explained by the level of serum anti-type $b$ antibody.

Rats also show an age-dependent susceptibility to $H$. influenzae (only young rats are susceptible) but this does not appear to be influenced by the level of serum antibody (Smith et al, 1973).

As the mouse would have been the most suitable animal from the point of view of availability and general convenience it was decided to investigate the possibilities of a mouse model for $H$. influenzae infections.

There are two reports of infection in young mice following injection of $\boldsymbol{H}$. influenzae: one describes injection of a mucin-enhanced suspension (Alexander et $a l, 1944)$ and the other injection of infected CSF from children suffering from meningitis (Wollstein, 1911). No report of the effect of injection of a known viable bacterial count of $\boldsymbol{H}$. influenzae in mice was found.

We carried out two experiments on 11 litters of strain CD-1 mice (Charles
Rivers (UK) Ltd) from 0 to 10 days old each litter containing between 8 and $15 \circ$ mice). $H$. influenzae type b (NCTC 8467) was grown in Brain Heart Infusion (fortified with haemin and NAD), washed, counted, and resuspended in PBS and $\widetilde{N}$ injected one hour later. Each mouse was injected (in the first experiment subcutaneously and in the second intra- $c$ peritoneally) with a $0.05 \mathrm{ml}$ suspension containing $10^{7}$ viable organisms. The 6 mice never looked ill and no deaths oc- $\mathbb{\perp}$ curred in either series of experiments. $\stackrel{?}{?}$ The animals were killed at five days, the blood expressed from the head was cultured, and $\boldsymbol{H}$. influenzae was isolated from two mice only, both in the intraperitoneal injection experiment-one from the newborn group and one from the one-day group. In a third experiment a massive 